\title{
Performance of village facilitators in sustainable community empowerment
}

\author{
Isra Djabbar*) \\ Universitas Sembilan Belas November Kolaka, Indonesia
}

\begin{tabular}{l} 
Article Info \\
\hline Article history: \\
Received Aug $30^{\text {th }}, 2021$ \\
Revised Sept $29^{\text {th }}, 2021$ \\
Accepted Oct $12^{\text {th }}, 2021$ \\
\hline
\end{tabular}

\section{Keyword:}

Performance

Companion

Village

Empowerment

\begin{abstract}
This study aimed to analyze and describe the performance of village assistants in sustainable community empowerment activities in Lalonaha Village, Wolo District, Kolaka Regency. Qualitative descriptive research method. Data obtained through interviews, literature study, and observation. The data analysis stage uses the Miles and Huberman method, namely data collection, data presentation, data verification, and concluding. Based on the research results, village assistants' capability in its implementation has not optimally because there are still many priority programs that people should expect but have not implemented. Activities carried out by village assistants in terms of development implementation, development supervision, and village administration training carried out by village assistants in Lalonaha Village, Wolo District have been able to run well, it is just that the obstacles faced regarding the quality of work by village assistants have not been able to carry out proper coordination fully. Both between the Lalonaha Village Government and the village community. In the implementation stage of village facilitator activities to help village government activities have not been able to run well, this is because in every development activity and supervision of development programs carried out more by the village apparatus themselves. The independence of village assistants in improving community empowerment in the village Lalonaha has not gone well because the village government itself carries out almost all the implementation of village assistance activities.
\end{abstract}

(C) 2021 The Authors. Published by IICET

This is an open access article under the CC BY-NC-SA license

(https://creativecommons.org/licenses/by-nc-sa/4.0)

\section{Corresponding Author:}

Isra Djabbar,

Universitas Sembilan Belas November Kolaka

Email: isradjabbar1@gmail.com

\section{Introduction}

Following the mandate of the law of the Republic of Indonesia concerning villages in 2014, the existence of village development is intended to improve the welfare and quality of life of The village community by encouraging the development of independent villages that are sustainable and have social, economic and environmental resilience. Efforts to reduce the gap between villages and cities are carried out by accelerating the development of independent villages. Therefore, in its implementation, the President stipulates a Presidential Regulation concerning the Ministry of Villages, Development of Disadvantaged Regions, and Transmigration. The village ministry forms Village Assistants who are placed in various regions, namely from the provincial, district, sub-district, and village levels.

As stated in the Ministerial Regulation concerning Village Assistance in articles 4 to 10, Village Facilitators state that Village Assistance is carried out by assistants consisting of professional assistants, village community 
empowerment cadres, and third parties. To assist the work of a Village Facilitator based at the sub-district level, it is deemed necessary to have a Village Local Assistant based directly in the village. Thus, a higher legal was issued than ministerial regulation number 3 in 2015, namely government regulation of the Republic of Indonesia, Number 47 in 2015 article 129, has added Village Local Assistants, including part of the Professional Assistance staff.

Village assistants on duty in community empowerment are a manifestation of the implementation of Law Number 6 in 2014 concerning Villages, contained in Chapter I General Provisions, namely in Article 1 paragraph 4 the first point contains Village community empowerment as an effort to develop independence and community welfare by increasing knowledge, attitudes, skills, behavior, abilities, awareness, and utilize resources through the establishment of policies, programs, activities, and assistance following the essence of the problem and priority needs of the Village community.

The performance of local village facilitators can be seen from several indicators, including the clarity of the objectives of village assistance following Ministerial Regulation Number 3 in 2015, the achievement strategy carried out by village assistance is adjusting to the rules where the strategy is both Musdes, RKPDes, and APBDes, analysis and policy formulation always side with the interests of the village and its community and the assistance party is always involved in policy formulation. Furthermore, village assistants have an important and needed role in addition to the administrative and financial management of village development and sustainable community empowerment, starting from planning, implementation, monitoring, evaluation, partnership, and independence. Village assistants need coordination and cooperation to form communication forums and working groups to conduct studies on problems, potentials, and prospects in village community development (Hilman et al., 2019).

Several studies have shown that the role of village facilitators is still not maximized and has not had a positive impact on the community. The results of research (Dianto, 2019) show that for four years, the village fund and village assistance program has been running, but not much has changed. This condition is influenced by the problems experienced by professional village assistants. There are four problematic aspects of professional village assistants: quantity, quality, division of labour, and coordination. Triyanto (2018) shows that the performance of village assistants has not been maximized, it can be seen from the cooperation built by Taba Jambu village assistants that have not been optimal, the cooperation that has just been carried out is only limited to collaboration with village communities and village government, has not collaborated with parties outside the village to improve the village economy, because it is constrained by the complexity of regulations from the local government, weak village management and the unavailability of qualified cadres in Taba Jambu Village.

Irfan \& Tahir (2020) shows that the role of village assistants in Karampi Village, Langgudu District, Bima Regency has not been influential because village assistants do not carry out functions in an integrated manner and together with the village government in building independent villages. However, the existence of village assistants is only as a survey team, data collection for reporting needs. Constraints for village assistants in carrying out their roles and functions are the existence of roads that are passed from one village to another, and the roads are quite damaged, there is a high sense of laziness, lack of work awareness, limited human resources, work discipline that is still neglected, low work responsibilities.

Research of Yuslaini \& Juliana (2019) that implementing the village assistance program in Bengkalis Regency has not been running as it should. Where the existence of village assistants in Bengkalis Regency still has an insignificant impact on increasing the capacity of village officials in Bengkalis Regency both in terms of capacity and effectiveness in increasing capacity, effectiveness and accountability of village government and village development, increasing initiatives, awareness, and participation of village communities in village development. Participatory, increasing the synergy of inter-sectoral village development programs and optimizing the village's local assets in an emancipatory manner. Based on observations and the results of interviews with various informants, it was found that the obstacles did not understand their function as village assistants, not being able to map local assets in Bengkalis Regency Village. Lack of coordination between village heads and village assistants in Bengkalis Regency, there are still many village heads who feel that the presence of village assistants does not significantly impact the capacity of village officials in Bengkalis Regency. Susanti (2015) also stated that the knowledge of the community who still does not know about the existence of village assistants, the presence of village assistants, assistance in program implementation, assistance in development supervision, communication with village assistants, in Sekodi village, Bengkalis subdistrict, Bengkalis Regency is considered not good. In fact, the community still disagrees $45.1 \%$ ( 32 people) with the sustainability of the program and there are even people who disagree 9.9\% (7 people) with the assistance, as well as development constraints that occur in the village still need strong improvements from the village assistant figure to really able and routinely carry out their duties as village assistants, so that community 
assessments are even better. However, there are still some respondents who want the sustainability of the village assistance program with an almost equal percentage of $45.1 \%$ (32 people).

The concept of mentoring in every government structure in Indonesia from the national level to the village level is a form of the Indonesian government's seriousness in overseeing development at every level of government. Currently, the concentration of attention is at the village level through the provision of professional personnel to optimize village government in budgets and community empowerment for village development. Village local assistants as a supporting element for the task of village assistants at the sub-district level. Considering the number of villages in each sub-district is different, and the problems faced by the villages are different. The existence of local village facilitators is necessary to assist village assistants at the sub-district level in reaching all villages. In Batu Layan Village, Padangsidimpuan District, this study found a gradual transformation of community participation from being passively paid to being active in village development programs. This process is the impact of the role of the Village Local Facilitator, who is responsive in implementing its functions and can synergize with the village government through an informal approach based on the values of local wisdom (Rambe et al., 2020).

Some of the reasons for the lack of optimization of village assistants in improving the human resources of rural communities are caused by (1) the study of the implementation of the Village Professional Assistance Program in the Village Community Development and Empowerment Program that has not been implemented optimally following the policy objectives that have been formulated, (2) Limited availability of available resources. Affect the implementation of the program, (3) Coordination, and communication between policy actors as an essential aspect in determining the success of program implementation has not been implemented effectively, (4) There is no straightforward Standard Operating Procedure (SOP) as a benchmark for program success (Sutanto, 2017).

Based on data in the field, initiatives, awareness, and community participation, in general, are still passive. The potential of natural resources in the village is still managed on a subsistence basis. People do not think business or commercial yet, but emphasize fulfilling family needs using simple technology. This condition is caused more by the inability to master technology, the relatively low level of public education, and the villagers' tendency to accept the conditions as they are. (M. H. Susanti, 2017) revealed that the obstacles faced by village facilitators were: 1) the low level of community education; 2) the number of village assistants; 3) the vacancy of the village head position; 4) limited access of farmers and small-scale business actors to business development capital, technology, and marketing networks; 5) limited infrastructure network and physical and economic facilities in supporting regional development; 6) the lack of professionalism and entrepreneurship from the community, and 7) not optimal support for local policies in favor of farmers and private business actors.

An institutional and financial strategy is constructed by establishing a 'mechanism' designed to distort the standard physical planning, community participation, and risk management procedures of democratic governance. These mechanisms enable disaster capitalism to materialize at all levels of society, rather than facilitating inclusive social learning, transformation, and building resilience. Contrary to the international DRR paradigm, a top-down, military-type process introduced after an earthquake disrupts local governance, exacerbates local vulnerability to disasters and endemic risks (such as corruption, elite capture, injustice, organized crime infiltration, public debt, rent-seeking, and social exclusion), and lead to failure to build the resilience of local communities. Therefore, community partners can assume autonomy or mutuality in criticizing governance for improving again (O'Hare, 2018).

The description above explains that it is necessary to have a village assistant to assist the government in providing village welfare through empowerment and activities carried out and tasked with overseeing and assisting the performance of the local village apparatus. Therefore, the author wants to know the extent of the role of the Village Facilitator in helping the government provide welfare to the people in Lalonaha Village, Wolo District, Kolaka Regency, and to create an independent village community like Nawacita, which President Jokowi and all of we expect.

In Lalonaha Village, empowerment activities that still lack community empowerment and community organizing show low community effort and independence. Human resource developments have not yet hit the target point. The government has issued a policy to develop and empower rural communities to become independent villages. With a high level of empowerment, the village community will solve the problems and affairs of their government. Community participation in planning, implementing, and supervising development carried out by the village government is believed to increase prosperity and create a prosperous society. So the government assigns a Village Assistant to assist the village government in developing and empowering village communities. 
The formulation of the problem in this study is how the performance of village assistants in sustainable community empowerment activities in Lalonaha Village, Wolo District, Kolaka Regency. This study aimed to analyze and describe the performance of village assistants in sustainable community empowerment activities in Lalonaha Village, Wolo District, Kolaka Regency.

\section{Method}

This type of research uses descriptive research with a qualitative approach by providing an overview of all problems regarding the performance of village assistants in community empowerment in Lalonahan Village, Wolo District, Kolaka Regency. The types and sources of data used in this study are primary data (sourced from interviews and field observations) and secondary data (from journals, theses, books, laws relating to this research). The data analysis technique in this study uses the Miles and Huberman interactive analysis model, namely data collection, data reduction, data presentation, and conclusion drawing (Miles \& Huberman, 1992). Data reduction is made by summarizing, choosing the main things, focusing on important things related to the performance data of village facilitators from the results of observations and interviews. Presentation of data is done in the form of descriptions, tables, or narrative text. Conclusions in this study are based on the presentation of data to obtain conclusions about the performance of village facilitators. The validity of the research data uses internal validity (source triangulation and method triangulation) and external validity (reference chart).

\section{Results and Discussions}

The performance or performance of village assistants in sustainable community empowerment activities in Lalonaha Village, Wolo District, Kolaka Regency is presented based on performance indicators, namely quality, quantity, timeliness, effectiveness, and independence.

\section{Village Companion Quality}

The duties of the Village Assistant in planning, implementing, and monitoring village development and empowerment of rural communities can be seen from the start of the plan in carrying out village deliberation together with the village community, village heads, and the village apparatus concerned and led by the village consultative body, making development plans and empowering democratically, creating participatory development, and conducting direct supervision of the process of development and empowerment of rural communities. Before carrying out the development program in the village, a joint discussion with the village government and also the village community was carried out to convey the development program to be carried out and also in this activity invited the community to get involved starting from planning and also implementing the development process, and this is the first step to started the task of empowering the community in Lalonaha Village. Problems that have not been channelled in terms of planning in village deliberations (MUSDUS) in Lalonaha Village, this activity aims at village development in terms of providing facilities and infrastructure such as tractors and opening farm roads to increase agricultural production, difficulty in making drainage which results in The frequent flooding when the rainy season arrives and the difficulty of providing clean water is no less important problems in Lalonaha Village. The village government supports this type of activity, whose budget resources are allocated later in the village budget. The results of the hamlet deliberations or the wishes of the community in hamlet II are achieved.

In village development program activities, the village government is assisted by village assistants starting from planning to implementing activities. The initial activity is holding deliberations at the hamlet level to find out proposals for development programs from the community. The village and the community to determine the development program that will be carried out in the village by involving the community. For development activities and village community empowerment, the village government and village assistants conduct village deliberations by involving the community to listen to input and feedback from the community regarding development programs that will be carried out, ranging from infrastructure development to improve the quality of agriculture and plantations. After the deliberation results are carried out, the next step is to determine the development program activities to be carried out together.

Village facilitators in carrying out their duties in community empowerment have been carried out. However, if we look further back at the maximum size in village assistance that village assistants have not carried out their duties optimally in terms of empowerment, previously we have discussed together with the problem of procuring agricultural seeds such as cocoa seeds, seeds cloves, rice seedlings, and nutmeg seedlings. We have also discussed how to make drainage during computer application activities so that the village government can fulfill them. However, more important things should be done during the 
implementation of activities but have not been implemented, such as procuring superior seeds for farming communities or plantation communities. The development program carried out in Lalonaha Village is to improve the welfare of the community. However, in its implementation, it optimally because there are still many priority programs that the community should expect but have not implemented, such as procuring superior seeds for the community, so that village assistants must further improve their performance in terms of helping village government activities and must also be closer to the village community so that problems that come from the village community accompanying the village immediately respond and report it to the village government to be followed up for the benefit of the village community.

\section{Village Companion Quantity}

From the interview results above regarding the quantity and quality of performance carried out by village assistants in terms of development implementation, development supervision and village administration training carried out by village assistants in Lalonaha Village, Wolo District. It has been able to run well, and it is just that the obstacles faced are regarding the quality of work by the village assistants. Village assistants have not been able to fully cooperate between the Lalonaha Village Government and the village community. In village financial reporting activities reported to the District Government are mainly carried out by the Village Government.

In addition to some of the problems above regarding the quality and strength of the performance of village assistants in Lalonaha Village, the thing that has failed in the successful performance of village facilitators is the implementation of village community empowerment. There are still empowerment activities carried out by institutional organizations in the village that should be supervised by village assistants instead. The Village Government itself did it, such as the PKK institutional empowerment activities and youth organizations, which should have received a response and assistance from village assistants. Instead, the activities were carried out separately, so the Village Government had to work hard in implementing government activities in the village.

On the other hand, the development and empowerment activities carried out in this village in their implementation are sourced from village funds, including the implementation of government by village officials, all have their respective portions, the development that is still ongoing is rural development starting from business roads. farming and temporary health facilities improvement in the field of empowerment is carried out by increasing the capacity of human resources in terms of increasing the capacity of agricultural land and plantations as well as improving institutional activities in the village such as workshop activities carried out by youth organizations and also training activities for village women who run by the PKK with a budget of Rp. 15,000,000.

The development and empowerment activities carried out in this village, especially in implementing the 2019 budget activity program, have entered the final stages starting from road construction activities, repairing public facilities and repairing village offices whose funds are sourced from village funds with a total budget of Rp. 835,250,000, including village community development activities of Rp. 138,400,000, including community empowerment with a total budget of Rp. 15,000,000, which is carried out in stages, the first stage is carried out for about six months, the second stage is carried out for about five months, and the budget for the salaries of village officials or village administration in Rp. 56,810,658.

625039342

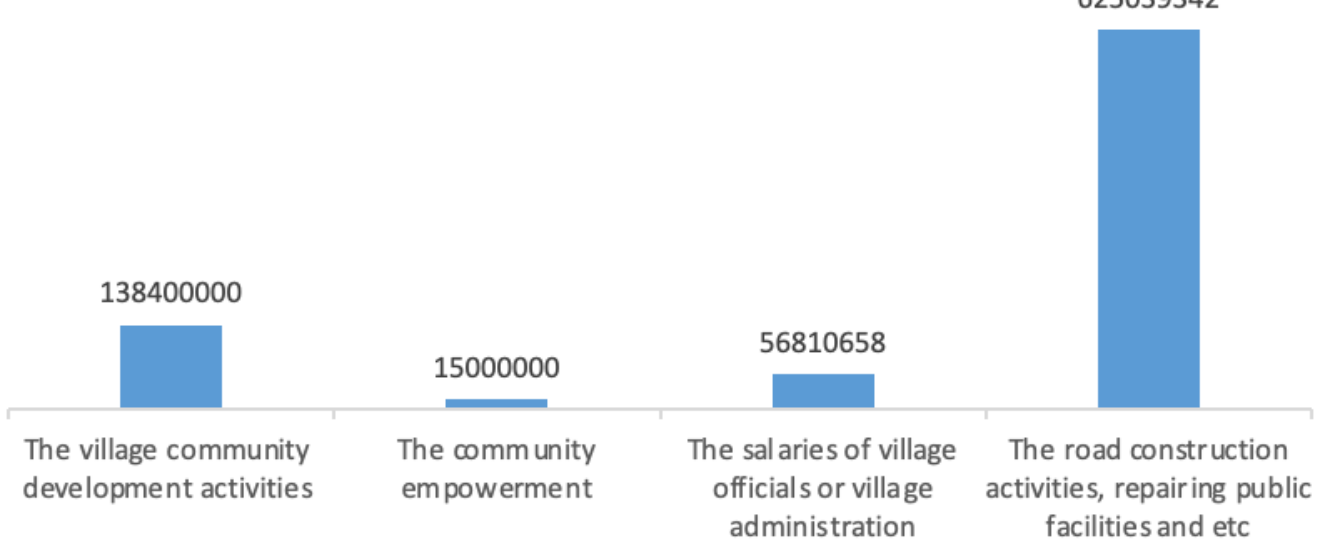

Figure 1. Village activities and budget for Lalonaha Village in 2019 
Village Assistant's Punctuality

Timeliness is the level of activity completed at the beginning of the stated time, from the point of view of coordinating with the output results and maximizing the time available for other activities. Based on the implementation of the Village Government Work Plan (RKP) guidelines for Lalonaha Village, Wolo District in the field of development and empowerment of rural communities, it turns out that it has not been able to be carried out optimally, this can be seen from the unfinished program of activities carried out based on the implementation time set in the 2019 RKP. There are still unfinished development programs such as repairing farm roads and repairing public facilities such as posyandu and places of worship, and also the evaluation stage is only carried out by the Lalonaha Village Government without any village assistants.

After this activity takes place, then an evaluation of each program that has been carried out, including the implementation of village government, is carried out. The implementation of development activities in this village until the end of 2019 has only partially been completed, such as repairing village offices and building deckkers, while repairing public facilities and building farm roads has not been completed, as well as the implementation of community empowerment such as PKK activities that have not been completed. In addition to the implementation of the village development sector, which the village government and village assistants carry out, community empowerment activities are also still an obstacle, such as PKK activities and also farmer groups which are still hampered in implementing the program and distributing aid funds so that we usually consult with village officials but so far have not carried out.

Based on the results of the interview above that in the implementation of performance by village assistants in assisting the activities of the Lalonaha Village Government both in the field of village development and also in the field of empowerment, it is carried out periodically through 2 stages of implementing activities contained in the village RKP with total funding sourced from the Village Fund (DD) in 2019 budget. Budget usage is presented in Table 1.

Table 1. Total RKP Village from the Village Fund for Fiscal Year 2019

\begin{tabular}{lr}
\hline \multicolumn{1}{c}{ Budget's utilization } & Cost (Rp) \\
\hline Administration of government & 835.250 .000 \\
Village community development & 138.400 .000 \\
Empowerment field & 15.000 .000 \\
Construction field & 838.250 .000 \\
Total & 1.573 .323 .020 \\
\hline
\end{tabular}

Table 1 shows that the funding comes from the Village Fund (DD) for the 2019 budget year with a total expenditure of $\mathrm{Rp}$. $1,573,323,020$, which is divided into the administration of $\mathrm{Rp}$. 835,250,000, village community development Rp. $138,400,000$ in the field of empowerment Rp. 15,000,000, construction sector Rp. 838,250,000, with a total expenditure of Rp. 1,521,012,328.

However, in the implementation stage, the performance of village assistants to assist village government activities has not been able to run well, this is because in every development activity and supervision of development programs carried out by village officials themselves, development programs carried out in Lalonaha Village have not been fully completed or completed, as well as the implementation of community empowerment and village community institutions which are still fully handled by the village government itself without being accompanied or supervised by village assistants, so that people who want to convey input and obstacles faced at the stage of implementing community empowerment such as empowering farmer groups and PKK activities as well as youth organizations, more are conveyed to the village government, as well as in evaluating each work program that has been carried out by the Lalonaha Village Government, Wolo District, they mostly work on their own without being accompanied by a supervisor. Village assistance.

\section{Village Facilitator Effectiveness}

The more plans that are successfully achieved, the more effective activity is. In the implementation of the performance carried out by the Village Facilitator in improving the welfare of the community in Lalonaha Village, Wolo District, Kolaka Regency to improve people's living standards.

For community empowerment activities in Lalonaha Village outside of village community institutions, it is in the agricultural sector. Before this activity is carried out, first conduct joint observations with local assistants and village communities and conduct discussions with several village communities regarding agricultural land and plantations' management. With various preparations, activities can be carried out and applied to farmer groups in Lalonaha Village for the cooperation built by the Lalonaha Village Government and agricultural extension workers in Wolo District. As well in the coaching carried out by village assistants in Lalonaha 
Village is coaching based on community groups by making efforts to improve the economy, namely making handicrafts and conducting training using computers, for the preparation of village reports.

The community empowerment program that we run together with the Village Government in Lalonaha Village is an empowerment and guidance program for farmer groups and community groups, with the form of the program being to provide agricultural guidance and assistance to farmer groups, to community groups by making efforts to improve the creative economy, namely making crafts and conduct computer training. For the preparation of other village reports, they no longer use a typewriter but use a computer with Microsoft Word, Excel, PowerPoint, and other applications.

For community empowerment programs that are run in Lalonaha Village, apart from empowering community institutions in the village such as youth organizations and PKK, we also empower community groups such as farmer groups and the creative economy and computer training-providing agricultural assistance and empowering community groups in collaboration with PKK to improve the family economy by making handicrafts with a selling value.

Based on the results of the interview, improving the performance of village assistants in community empowerment, especially in community groups, was carried out by involving several related parties such as agricultural extension workers at the Walo District level to provide agricultural guidance and assistance for farmer groups, and community groups by involving the role of PKK to grow the economy. The family has selling value so that the community can develop and be independent.

\section{Village Assistant Independence}

Independence is seen as organizing one's work properly according to the expected target without giving detailed instructions. Independence is related to one's maturity or level of maturity (maturity) in work.

The independence of village assistants in carrying out their performance to improve community welfare is being able to provide understanding and convenience to both the village government and the village community. The independence of village assistants in carrying out their performance is also closely related to overcoming problems in the community environment and community organization institutions. Be taken into consideration in the implementation of village government through the field of empowerment to be carried out together with the village government. For the implementation of the programs that we run, especially in the field of ordinary empowerment, we see firsthand the condition of the village community, both community groups and village institutional organizations, in order to find out the problems faced and then we will discuss them together with the village government so that they can be included in the implementation of empowerment activity programs following the conditions required. Exist in society. In the implementation of the field of village community empowerment, both social groups in the village, such as farmer groups and others as well as institutional organizations in our village, the village government together with village assistants, usually discuss with the community on existing problems and the wishes of the community, all of which are accommodated for further discussion together so that can be included in the implementation of the program of activities. Village assistant activities in implementing community empowerment programs in the village, with the first step being to see firsthand the problems faced by the village community and also the wishes of the community, which will later be held in a joint meeting to discuss the existing problems and will later be included in the government's development plan. Village through empowerment.

Independence from village assistants to carry out their performance through duties and functions to assist the implementation of village government, especially in the field of community empowerment, is carried out by jointly seeing firsthand the conditions faced by village communities both through social groups and institutional organizations in the village and listening to every input from the community to be followed up in the program implementation activities.

The implementation of the performance of village assistants in Lalonaha Village in assisting government activities in improving the welfare of rural communities is to pay attention to the conditions and wishes of the community so that the village government determines the program reaches the community. However, the independence of the performance of village assistants has not been fully able to run well. because village officials carry out almost all consultation activities in the community for consultation and to see conditions directly in the community and to listen to input from the community is carried out by village assistants together with the village government, which we will discuss together in the work program, I only usually hear from the community assistants are still less active in socializing with the community, especially in community groups and in institutional organizations in the village. On the other hand, interactions between village communities and village assistants only occur during activity monitoring. Meanwhile, more socialization is carried out by village officials. Based on the results of the interview above that the independence of the performance of village assistants in improving community empowerment in Lalonaha Village has not gone 
well because almost all the implementation of village facilitator activities, especially in direct contact with the community to find out the conditions faced by the community and input given by the community is mainly done. By the village government itself, and will later be included in the village work program.

\section{Conclusions}

The performance of village assistants in sustainable community empowerment in Lalonaha Village, Wolo District, Kolaka Regency encountered many obstacles. The small number of village assistants becomes a problem with the condition of 1 village assistant accommodating more than one village. There are still many priority programs that people should expect but have not implemented, such as procuring superior seeds for farming communities and other community institutions in the village. In this case, the impact on village assistants has not been able to fully cooperate between the Lalonaha Village Government and the village community, so that village financial reporting activities reported to the District Government are mainly carried out by the Village Government itself. The village apparatus themselves mainly carry out every development activity and supervision of development programs that are carried out. In improving the performance of village assistants in community empowerment, it can be done well, especially in community groups, by involving several related parties such as agricultural extension workers at the Walo District level to provide agricultural guidance and assistance for farmer group communities.

\section{References}

Alers, S., Wesselborg, S., \& Stork, B. (2014). ATG13: just a companion, or an executor of the autophagic program?. Autophagy, 10(6), 944-956.

Bintoro, \& Daryanto. (2017). Manajemen Penilaian Kinerja Karyawan. Cetakan 1. Gava Media.

Cane, P., \& Conaghan, J. (2008). The new Oxford companion to law.

Carlson, M. (2013). Performance: A critical introduction. Routledge.

Dianto, I. (2019). Problematika Pendamping Desa Profesional dalam Pemberdayaan Masyarakat Desa di Kota Padangsidimpuan. Dimas: Jurnal Pemikiran Agama untuk Pemberdayaan, 18(2), 239. https://doi.org/10.21580/dms.2018.182.2829

Duflo, E. (2012). Women empowerment and economic development. Journal of Economic literature, 50(4), 1051-79.

Hilman, L., Cikusin, Y., \& Abidin, A. Z. (2019). Efektifitas Kinerja Pendamping Lokal Desa Dalam Pembangunan Desa (Studi di Desa Jambu Kecsmatan Lenteng Kabupaten Sumenep). Respon Publik, 13(3), 90-95.

Huang, M., Li, F., Dong, F., Zhang, Y. X., \& Zhang, L. L. (2015). MnO 2-based nanostructures for highperformance supercapacitors. Journal of Materials Chemistry A, 3(43), 21380-21423.

Irfan, I., \& Tahir, M. (2020). Peran Pendamping Desa Dalam Mewujudkan Desa Mandiri (Studi di Desa Karampi Kecamatan Langgudu Kabupaten Bima). EDU SOCIATA (Jurnal Pendidikan Sosiologi), 4(1), 37-48. https://doi.org/10.33627/es.v4i1.410

Miles, \& Huberman. (1992). Analisis Data Kualitatif. Dialih bahasakan oleh Tjetjep Rohendri Rohidi. ,. PT Remaja Rosdakarya.

Murti, E., Harianto, \& Iswati, R. (2020). Pengaruh program satu desa satu produk (one village one product), terhadap pengembangan ekonomi desa. Seminar Nasional Sistem Informasi 2020-UNMER Malang.

O'Hare, P. (2018). Resisting the 'Long-Arm' of the State? Spheres of Capture and Opportunities for Autonomy in Community Governance. International Journal of Urban and Regional Research - Wiley Online Library. https://onlinelibrary.wiley.com/doi/abs/10.1111/1468-2427.12606

Peraturan Menteri Desa, Pembangunan Daerah Tertinggal, Dan Transmigrasi Republik Indonesia Nomor 3 Tahun 2015 Tentang Pendampingan Desa

Peraturan Pemerintah Republik Indonesia No 47 Tahun 2015 perubahan atas peraturan pemerintah nomor 43 tahun 2014 tentang peraturan pelaksanaan undang-undang nomor 6 tahun 2014 tentang Desa.

Peraturan Presiden Nomor 12 tahun 2015 tentang Kementerian Desa, Pembangunan Daerah Tertinggal dan Transmigrasi

Porter, M. (2003). The economic performance of regions. Regional studies, 37(6-7), 549-578.

Rambe, J., Badaruddin, B., \& Kadir, A. (2020). Konsep Pendampingan dalam Struktur Pemerintahan Indonesia: Mengapa Pendamping Lokal Desa Harus Ada? PERSPEKTIF, 9, 263-269. https://doi.org/10.31289/perspektif.v9i2.3545

Susanti, M. H. (2017). Peran Pendamping Desa Dalam Mendorong Prakarsa Dan Partisipasi Masyarakat Menuju Desa Mandiri Di Desa Gonoharjo Kecamatan Limbangan Kabupaten Kendal. Integralistik, 28(1), 29-39. https://doi.org/10.15294/integralistik.v28i1.11809 
Susanti, R. (2015). Efektivitas Pendampingan Desa Dan Partisipasi Masyarakat Dalam Pembangunan Infrastruktur Pedesaan Di Desa Sekodi Kecamatan Bengkalis Kabupaten Bengkalis. Jom FISIP, 2(1).

Sutanto, S. L. (2017). Implementasi Program Pendamping Profesional Desa: Program Pembangunan Dan Pemberdayaan Masyarakat Desa (P3md) Di Kabupaten Bojonegoro. Badan Penelitian dan Pengembangan Provinsi Jawa Timur.

Triyanto, D. (2018). Analisis Kinerja Pendamping Desa Dalam Upaya Membangun Kemandirian Desa. MIMBAR: Jurnal Penelitian Sosial Dan Politik, 7(2), 56. https://doi.org/10.32663/jpsp.v7i2.669

Undang-Undang Nomor 9 Tahun 2015 Tentang Pelaksanaan Pemerintahan Daerah.

Undang-Undang Nomor 6 Tahun 2014 Tentang Desa.

Wibowo. (2013). Manajemen Kinerja. Edisi Ketiga. Jakarta: PT Raja Grafindo Persada.

Yuslaini, N., \& Juliana, S. (2019). Evaluasi Program Pendamping Desa Di Kabupaten Bengkalis. WEDANA: Jurnal Kajian Pemerintahan, Politik Dan Birokrasi, 5(2), 7-15. https://doi.org/10.25299/wedana.2019.vol5(2).4180

Zimmerman, M. A. (2000). Empowerment theory. In Handbook of community psychology (pp. 43-63). Springer, Boston, MA.

Zollo, M., \& Meier, D. (2008). What is M\&A performance?. Academy of management perspectives, 22(3), 5577. 